



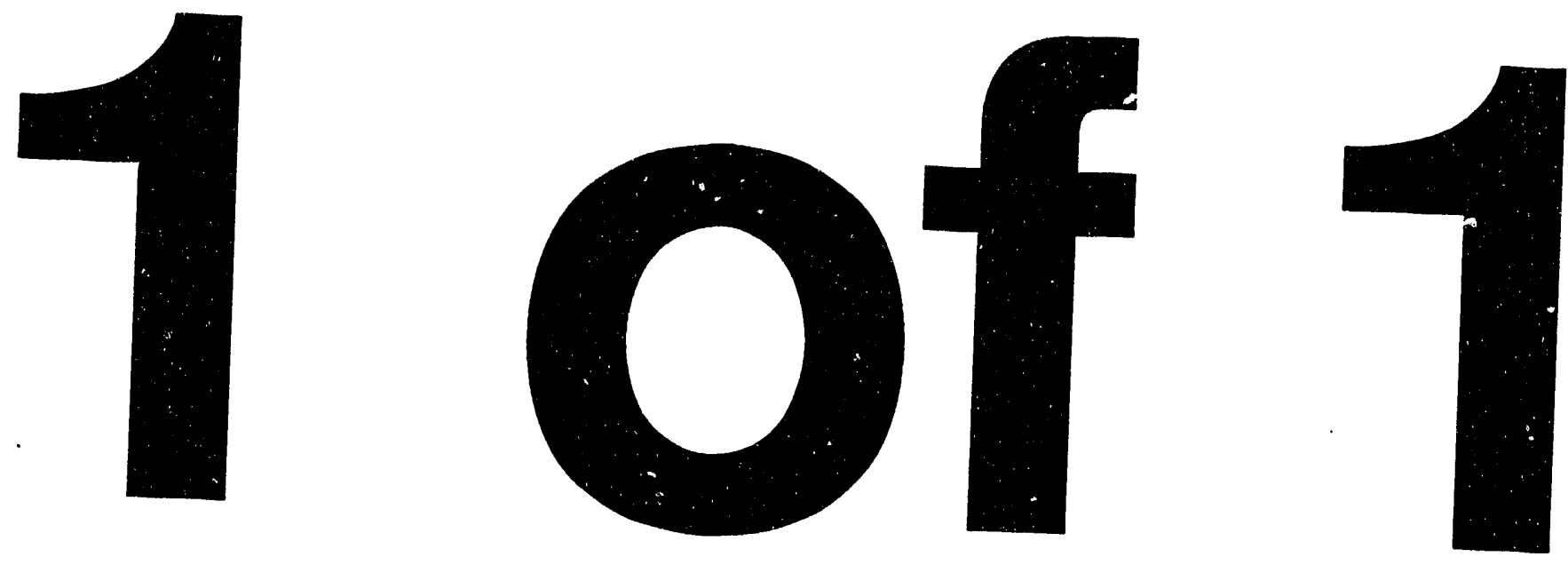
INDIVIDUAL AND POPULATION DOSE TO USERS OF THE SAVANNAH RIVER FOLLOWING K-REACTOR TRITIUM RELEASE (U)

by

WSRC Contact - W. H. Carlton

Westinghouse Savannah River Company

Savannah River Site

Aiken, South Carolina 29808

D. M. Hamby

WSRC

This paper was prepared in connection with work done under the above contract number with the U. S. Department of Energy. By acceptance of this paper, the publisher and/or recipient acknowledges the U. S. Government's right to retain a nonexclusive, royalty-free license in and to any copyright covering this paper, along with the right to reproduce and to authorize others to reproduce all or part of the copyrighted paper. 


\section{DISCLAIMER}

This report was prepared as an account of work sponsored by an agency of the United States Government. Neither the United States Government nor any agency thereof, nor any of their employees, makes any warranty, express or implied, or assumes any legal liability or responsibility for the accuracy, completeness, or usefulness of any information, apparatus, product, or process disclosed, or represents that its use would not infringe privately owned rights. Reference herein to any specific commercial product, process, or service by trade name, trademark, manufacturer, or otherwise does not necessarily constitute or imply its endorsement, recommendation, or favoring by the United States Government or any agency thereof. The views and opinions of authors expressed herein do not necessarily state or reflect those of the United States Government or any agency thereof.

This report has been reproduced directly from the best available copy.

Available to DOE and DOE contractors from the Office of Scientific and Technical Information, P. O. Box 62, Oak Ridge, TN 37831; prices available from (615) $576-8401$.

Available to the public from the National Technical Information Service, U. S. Department of Commerce, 5285 Port Royal Rd., Springfield, VA 22161. 
January 29, 1992

\author{
œ: R.T. Begley, 773A \\ W.H. Carlton, 773A \\ A.G. Evans, 735-7A \\ T.F. Heenan, 703-A \\ J.D Heffner, 735A \\ L. Papouchado, 773A \\ J.S. Roberts, 742A \\ S.R. Wright, 703-41A \\ EDG Files (2)
}

TO: A.L. Boni, 773A

FROM: D.M. Hamby, 773A (5-3042)

\title{
INDIVIDUAL AND POPULATION DOSE TO USERS OF THE SAVANNAH RIVER FOLLOWING K-REACTOR TRITIUM RELEASE
}

\section{SUMMARY}

Approximately 5700 curies of tritium were released to Pen Branch between December 22 , 1991 and December 25, 1991. As expected, the tritiated water traveled through the Savannah River swamp to Steel Creek and the Savannah River. Elevated tritium concentrations in the river at Becks Ferry (Beaufort-Jasper) and Abercorn Creek (Port Wentworth) has caused some concern among downstream water users as to the amount of tritium available for uptake through the domestic drinki , water supplies at the BeaufortJasper and Port Wentworth water treatement facilities. Radiation dose to the downstream drinking water population is estimated in this report.

Measurements, however, of tritium in the Savannah River at several locations indicates that the release was limited to about 5700 curies and the river flow rate averaged nearly 9000 $\mathrm{ft}^{3} / \mathrm{sec}$ during the period. In addition, Beaufort-Jasper reduced its intake of Savannah River water and used its alternate source of stored water. Radiation dose to the maximum individual, average individuals and the population are given in Table 1 for exposure pathways of drinking water, fish and oyster ingestion. The derivation of each value is described below.

Dose limits, set forth by EPA and DOE, apply to radiation doses received from exposures through the drinking water pathway and for all other pathways. The most restrictive dose limits are $4 \mathrm{mrem} / \mathrm{yr}$ for the drinking water pathway, as established in 40 CFR 141, and 
$100 \mathrm{mrem} / \mathrm{yr}$ for all pathways and all nuclides, stated in DOE Order 5400.5. DOE has also established a reporting limit of $10 \mathrm{mrem} / \mathrm{yr}$ for releases of DOE sources.

Table 1. Summary of radiation dose to users of the Savannah River following the KReactor aqueous tritium release.

\begin{tabular}{lccc}
\hline & Beaufort-Jasper & Port Wentworth & \\
Pathway & $(50,000)$ & $(15,000)$ & Hwy 301
\end{tabular}

Max Individual Dose (mrem)

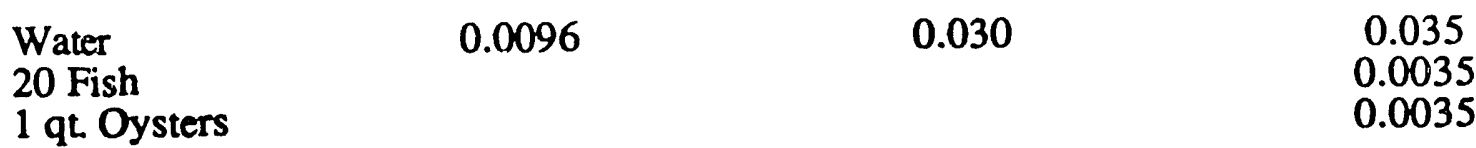

Avg. Individual Dose (mrem)

$\begin{array}{lll}\text { Water } & 0.0048 & 0.015\end{array}$

Population Dose (person-rem)

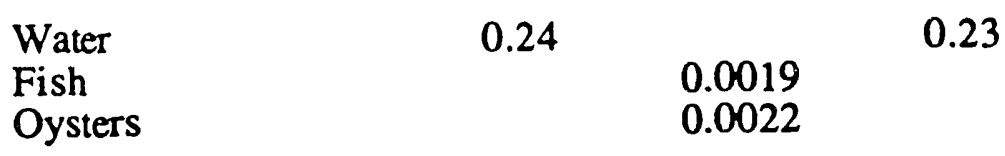

Note: Food processing plants at Port Wentworth were closed during the period of elevated tritium concentrations in the Savannah River.

\section{CALCUlation OF POPUlation dOSE}

The population dose to users of the Savannah River for domestic water is es:umated assuming that each individual on the water system consumes one liter of water per day for a specified number of days. Population dose via water ingestion is estimated by:

$$
D=(P)(C)(I)(t)(D F)
$$

where $\mathrm{P}$ is the population, $\mathrm{C}$ represents tritium concentration in the drinking water, $\mathrm{I}$ is the intake rate, $t$ is the time over which the dose is integrated, and DF is the internal tritium dose factor. In this report, concentration is expressed in units of $\mathrm{pCi} / \mathrm{mL}$, intake in units of $\mathrm{mL} /$ day, time is in days, and the dose factor is in units of rem/pCi. The tritium dose factor for ingestion is $6.3 \times 10^{-11} \mathrm{rem} / \mathrm{pCi}$.

Tritium concentrations in the Savannah River at Becks Ferry and Abercorn Creek began to rise on December 28, 1991 returned to normal levels about January 10, 1992 (see Figure 1). Subsequent days were slightly elevated due to routine SRS releases. The population dose resulting from the K-Reactor release will be calculated for the consumption of drinking water during the time when elevated tritium concentrations are present in finished water at Beaufort-Jasper and Port Wentworth. 
Drinking water dose to the average individual has been estimated by dividing the population dose by the total number of people making up the population. Individual dose to the maximum user has been estimated by multiplying the average dose by a factor of 2 to account for twice the intake ( $2 \mathrm{~L} /$ day for a maximum individual; $1 \mathrm{~L} /$ day for an average individual).

\section{DRINKING WATER DOSE}

\section{Beaufort-Jasper}

ETS collected raw and finished water samples at the Beaufort-Jasper water treatment plant from Dec. 26 to Jan. 7 and from Jan. 16 to Jan. 27. These concentrations are plotted against each other in Figure, 2. A line of slope 1 has been added to the graph. The figure shows that daily tritium concentrations are virtually identical in the raw and finished water. These data also show that holdup times are generally less than about one day. Finished water concentrations for the period between Jan. 8 and Jan. 15 are estimated using concentrations measured at the Beaufort-Jasper system intake.

Figure 3 shows the measured concentrations in Beaufort-Jasper finished water from January 10 to January 27 . Concentrations were elevated above normal values during this period.

Dose to the population consuming domestic water from the Beaufort-Jasper system is estimated in Table 2. Daily average tritium concentrations used in the calculation are shown in the table. Total population dose to the 50,000 consumers at Beaufort-Jasper was approximately 0.24 person-rem. For the Beaufort-Jasper water supply system, the average individual dose was about $0.0048 \mathrm{mrem}$. The maximum individual dose is estimated to be approximately $0.0096 \mathrm{mrem}$.

The maximum individual at Beaufort-Jasper received a much lower dose than the hypothetical individual at the Highway 301 bridge. This occurs because the BeaufortJasper water treatment facility shut down its pumps during the tritium passage, thereby lessening the amount the tritium drawn into their system.

\section{Port Wentworth}

Measurements of tritium concentrations in the finished water of the Port Wentworth water treatment facility from December 28, 1992 to January 14, 1992 are shown in Figure 4. Also appearing in the figure are the average daily concentrations of tritium in Abercorn Creek, the water source for the Port Wentworth intake. Finished water concentrations for Dec. 28 and 29 were unavailable. Therefore, finished concentrations for those days are estimated to be equal to the concentrations in Abercorn Creek. 
Table 2. Tritium concentration and dose from consumption of water at Beaufort-Jasper ${ }^{\dagger}$.

\begin{tabular}{|c|c|c|}
\hline Date & Concentration (pCi/mL) & Dose (person-rem) \\
\hline Jan. 10 & 2.53 & $8.0 \times 10^{-3}$ \\
\hline Jan. 11 & 2.71 & $8.5 \times 10^{-3}$ \\
\hline Jan. 12 & 2.23 & $7.0 \times 10^{-3}$ \\
\hline Jan. 13 & 1.88 & $5.9 \times 10^{-3}$ \\
\hline Jan. 14 & 3.53 & $1.1 \times 10^{-2}$ \\
\hline Jan. 15 & 2.99 & $9.4 \times 10^{-3}$ \\
\hline Jan. 16 & 7.08 & $2.2 \times 10^{-2}$ \\
\hline Jan. 17 & 7.50 & $2.4 \times 10^{-2}$ \\
\hline Jan. 18 & 6.02 & $1.9 \times 10^{-2}$ \\
\hline Jan. 19 & 5.04 & $1.6 \times 10^{-2}$ \\
\hline Jan. 20 & 3.95 & $1.2 \times 10^{-2}$ \\
\hline Jan. 21 & 4.93 & $1.6 \times 10^{-2}$ \\
\hline Jan. 22 & 4.61 & $1.5 \times 10^{-2}$ \\
\hline Jan. 23 & $5.0 \overline{3}$ & $1.6 \times 10^{-2}$ \\
\hline Jan. 24 & 4.17 & $1.3 \times 10^{-2}$ \\
\hline Jan. 25 & 3.82 & $1.2 \times 10^{-2}$ \\
\hline Jan. 26 & 3.69 & $1.2 \times 10^{-2}$ \\
\hline \multirow[t]{2}{*}{ Jan. 27} & 3.45 & $1.1 \times 10^{-2}$ \\
\hline & TOTAL & $2.4 \times 10^{-1}$ \\
\hline
\end{tabular}

†water concentrations at BJ intake ( 50,000 consumers).

Dose to the Port Wentworth drinking water population is shown in Table 3. Daily average concentrations in the finished Port Wentworth water supply is given along with daily population dose. The Port Wentworth water treatment facility supplies water to an industrial park near Savannah, Georgia. Approximately 15,000 individuals work at various industries in the park. For conservatism, it is assumed that each employee consumes one liter of water (at work) each day, including weekends and holidays. This high degree of conservatism more than accounts for the exposure pathway presented by manufactured products containing very small amounts of tritium resulting from the use of river water during the period of the release. The population dose, between Dec. 28 and Jan 15., to the Port Wentworth water users was approximately 0.23 person-rem. The dose to the average individual consuming Port Wentworth water was about $0.015 \mathrm{mrem}$ and the dose to the maximum individual is about $0.030 \mathrm{mrem}$.

The hypothetical maximum dose at Port Wentworth is comparable to the dose received by the maximum individual at Highway 301. Port Wentworth managed its pumping schedule during low tides to reduce the tritium intake, however, increased concentrations were measured in finished water supplies. The maximum dose of $0.030 \mathrm{mrem}$ is estimated assuming that an individual drinks two liters of water each day, while working at the Savannah River industrial park. Notices were displayed, however, at drinking fountains 
Table 3. Tritium concentration an dose from consumption of water at Port Wentworth ${ }^{\dagger}$.

Date Concentration $(\mathrm{pCi} / \mathrm{mL}) \quad$ Dose (person-rem)

Dec. $28^{*}$

Dec. $29^{*}$

Dec. 30

Dec. 31

Jan. 1

Jan. 2

Jan. 3

Jan. 4

Jan. 5

Jan. 6

Jan. 7

Jan. 8

Jan. 9

Jan. 10

Jan. 11

Jan. 12

Jan. 13

Jan. 14
3.95

19.48

26.71

23.57

26.76

23.28

22.76

19.59

16.46

10.40

10.57

7.81

5.33

6.34

5.49

4.77

5.79

2.44
$3.7 \times 10^{-3}$

$1.8 \times 10^{-2}$

$2.5 \times 10^{-2}$

$2.2 \times 10^{-2}$

$2.5 \times 10^{-2}$

$2.2 \times 10^{-2}$

$2.2 \times 10^{-2}$

$1.9 \times 10^{-2}$

$1.6 \times 10^{-2}$

$9.8 \times 10^{-3}$

$1.0 \times 10^{-2}$

$7.4 \times 10^{-3}$

$5.0 \times 10^{-3}$

$6.0 \times 10^{-3}$

$5.2 \times 10^{-3}$

$4.5 \times 10^{-3}$

$5.5 \times 10^{-3}$

$2.3 \times 10^{-3}$

TOTAL

$2.3 \times 10^{-1}$

$T_{\text {water concentrations of finished } P W}$ water $(15,000$ consumers).

* data not available, values determined from average of measured concentrations in Abercom Creek.

warning against the consumption of water during times of elevated concentrations. It is presumed, therefore, that the maximum (and average) dose is much larger than actually received.

\section{DOSE VIA AQUATIC FOODS INGESTION}

Individual and population doses are estimated below for the consumption of fish and oysters that may have been harvested during the K-Reactor release. These estimates demonstrate the insignificance of the aquatic foods pathway, relative to drinking water, following an aqueous tritium release.

In 1989 , approximately $37,700 \mathrm{~kg}$ of fish meat was harvested (both sport and commercial) from the Savannah River and its estuaryt. If fish are harvested from the river at a constant rate during the year, the annual catch for a two-week period could be estimated at about $1433 \mathrm{~kg}$ of fish meat ( $1330 \mathrm{~kg}$ sport; $103 \mathrm{~kg}$ commercial). The average tritium concentration in fish caught by sport fisherman during the two-week period from December 26,1991 to January 8,1992 is estimated from the average concentration in water at

${ }^{\dagger}$ Hamby, D.M., "Land and Water Usage Characteristics in the Vicinity of the Savannah River Site", WSRC-RP-91-17, March 1991. 
Highway 301 for the same period $(22.3 \mathrm{pCi} / \mathrm{mL})$. Concentrations in commerically harvested fish for a two-week period are determined from average concentrations in water at Fort Pulaski $(6.47 \mathrm{pCi} / \mathrm{mL})$. If all $1433 \mathrm{~kg}$ of fish meat were consumed, the population dose would be 0.0019 person-rem.

The total amount of edible meat from invertebrates harvested in the Savannah River estuary in 1989 was about $390,000 \mathrm{~kg}$ (includes crab, shrimp, oysters, and clams). The harvest for a two week period, therefore, is estimate to be approximately $14,820 \mathrm{~kg}$. The tritium concentration in all invertebrates is estimate from actual measurements of oysters harvested at Fort Pulaski. An average tritium concentration of $2.32 \mathrm{pCi} / \mathrm{mL}$ is assumed. If the twoweek invertebrate harvest were consumed, the population dose would be 0.0022 personrem. 
Figure 1. Tritium concentration in the Savannah River

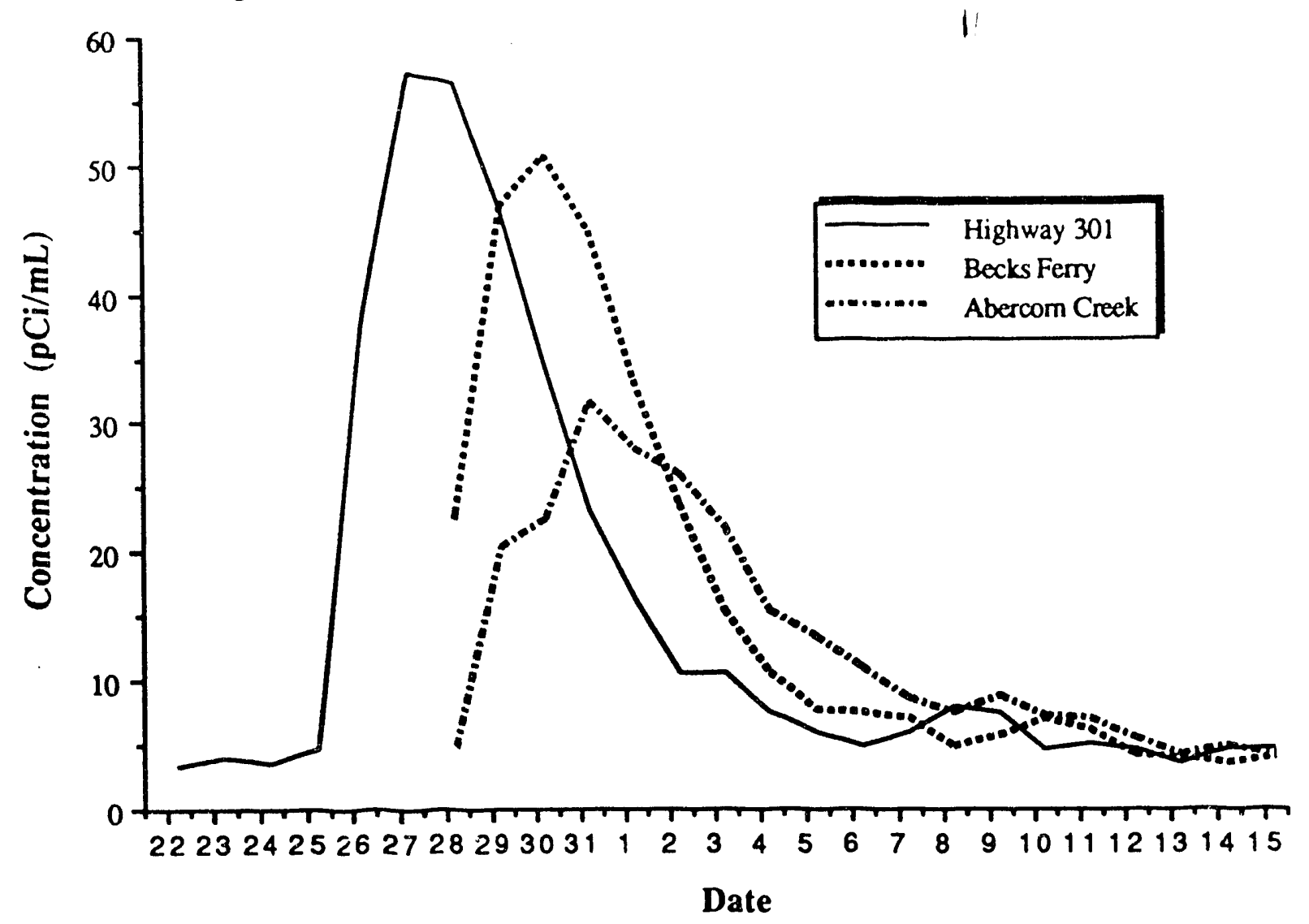

Figure 2. Tritium concentration of raw vs finished water at Beaufort-Jasper

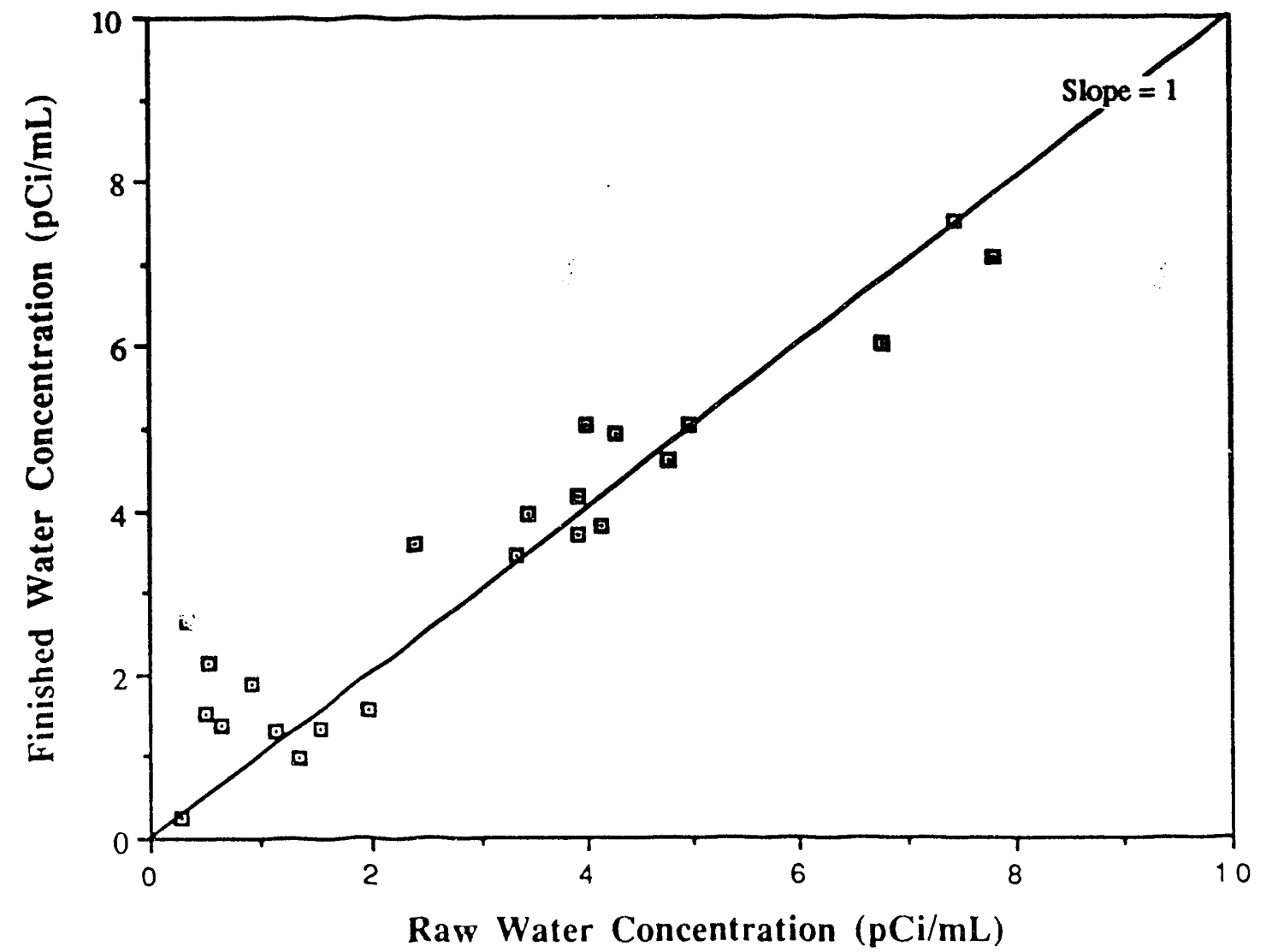


Figure 3. Tritium concentration in finished water at Beaufort-Jasper

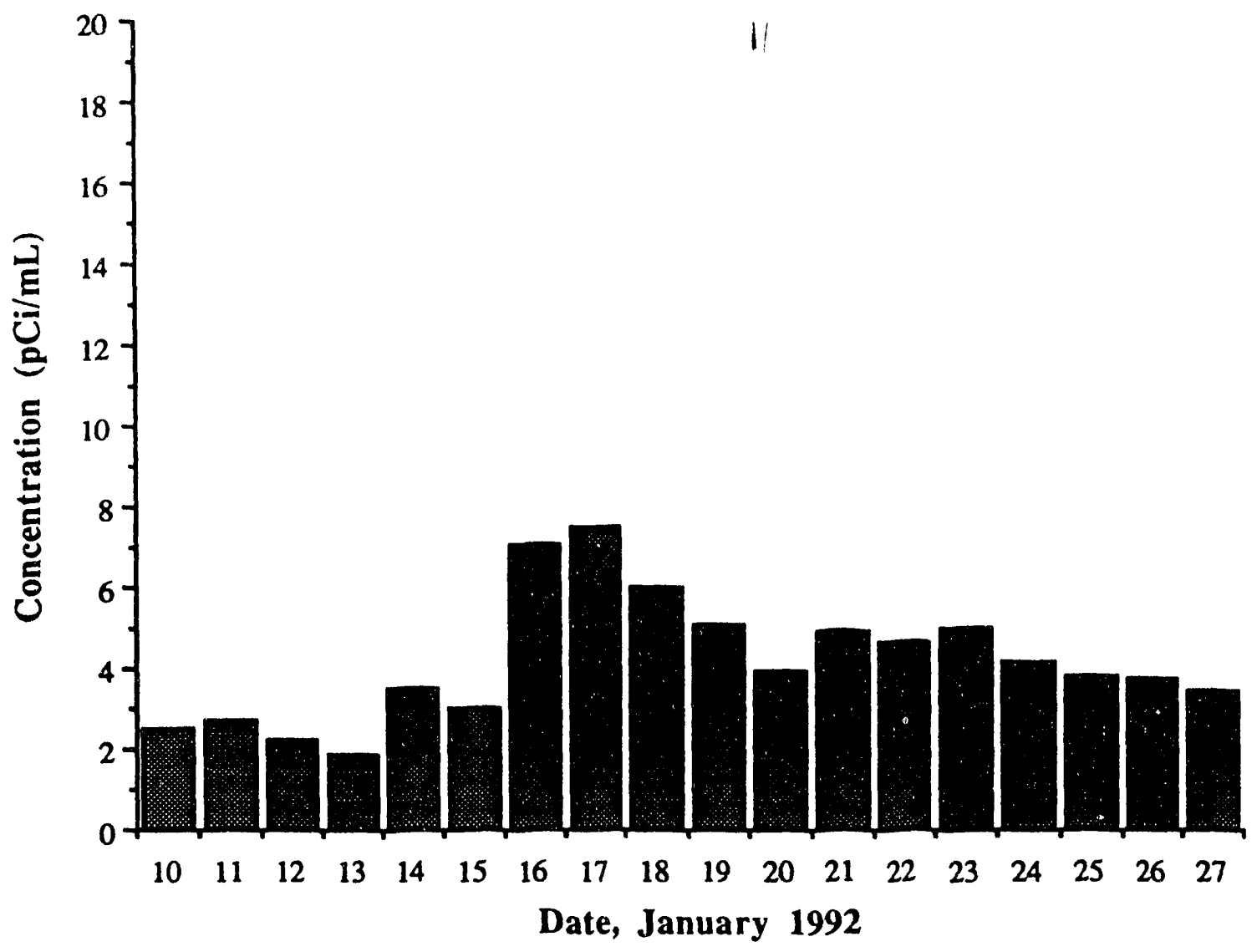

Figure 4. Tritium concentrations at Port Wentworth

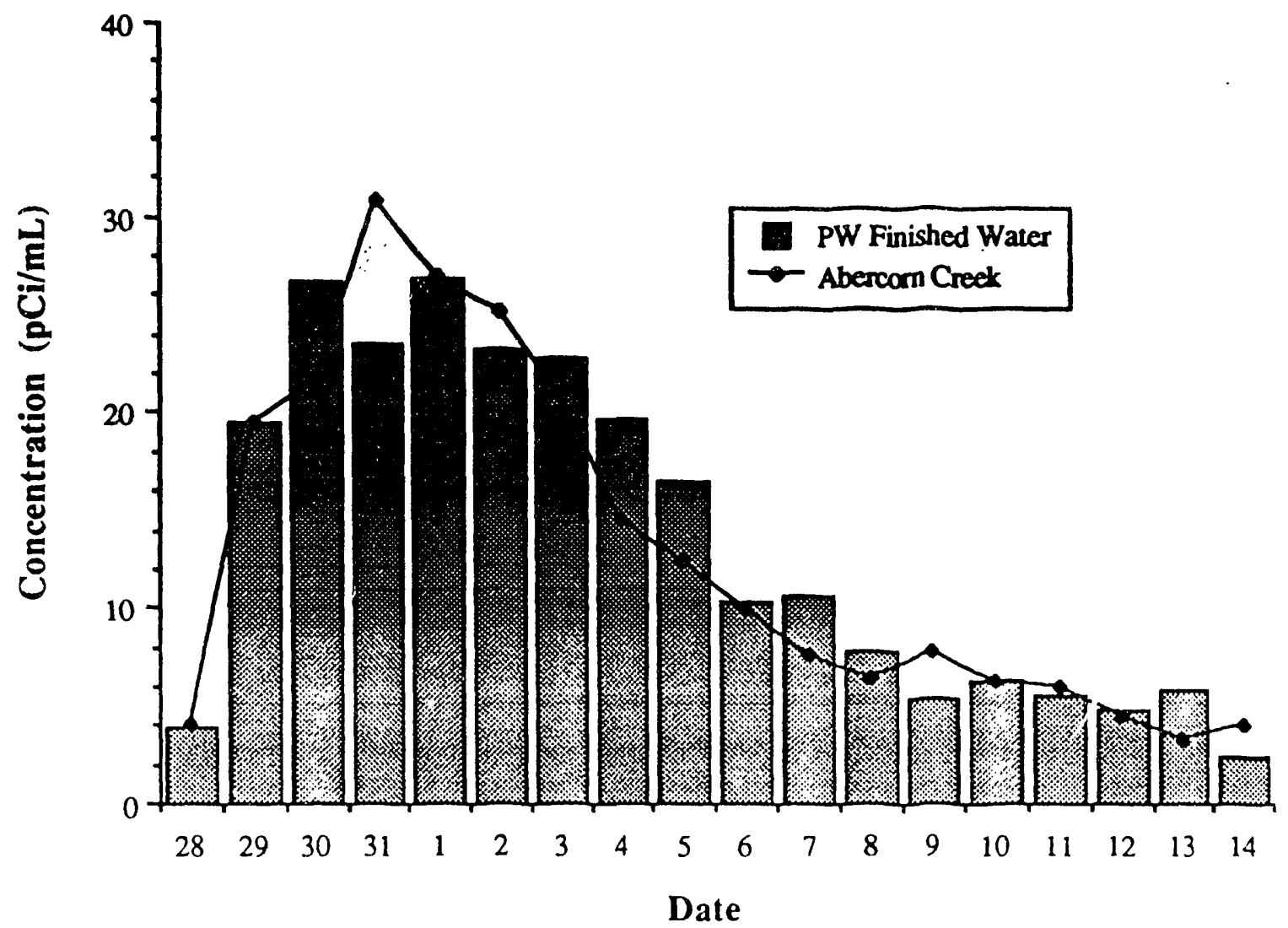



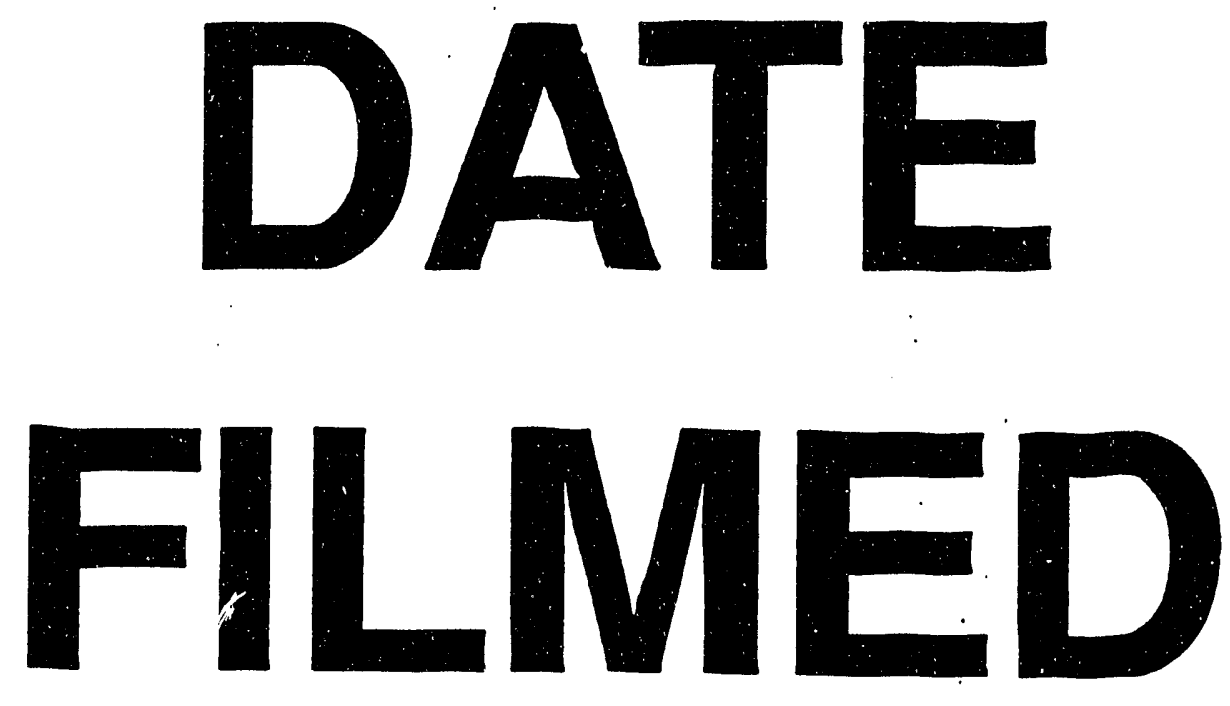

$10 / 15 / 93$
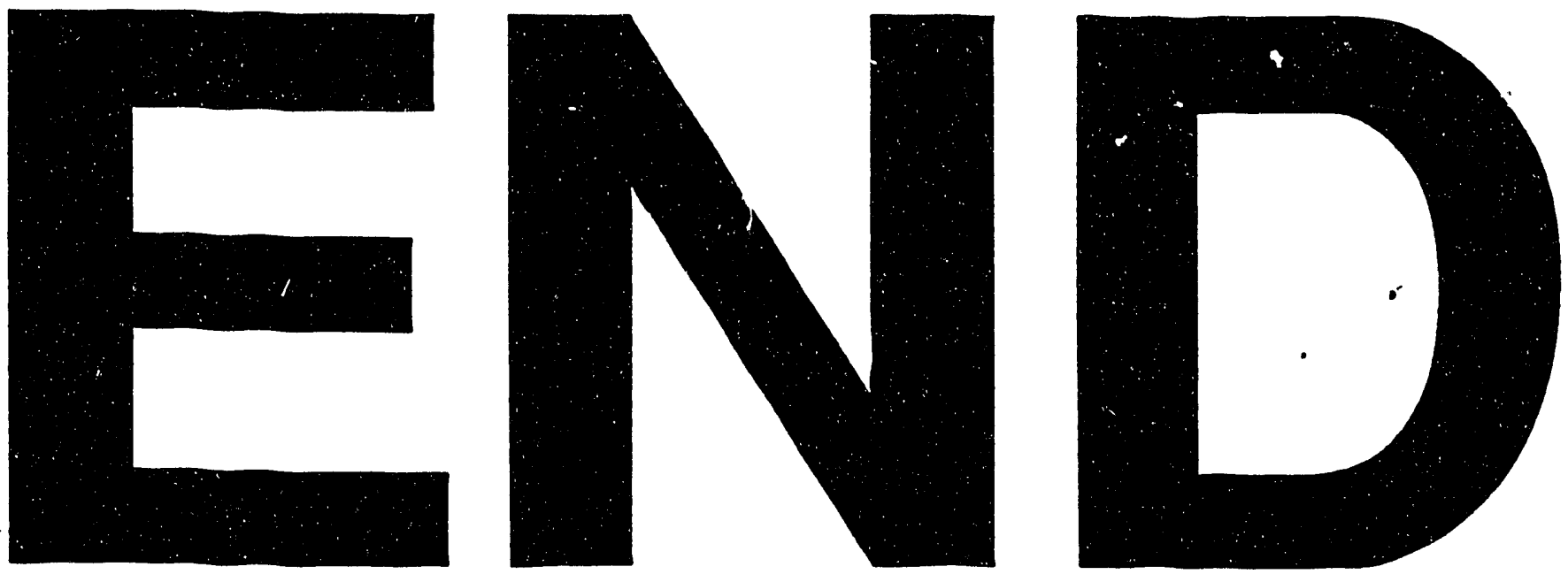